\title{
PROBABILITY OF INFECTIOUS DISEASE IN HUMANS DURING EPIDEMIC
}

Karmishin $\mathrm{AM}^{1} \otimes$, Borisevich $\mathrm{IV}^{2}$, Skvortsova VI ${ }^{2}$, Goryaev $\mathrm{AA}^{1}$, Yudin $\mathrm{SM}^{1}$

${ }^{1}$ Center for Strategic Planning and Management of Medical and Biological Health Risks of the Federal Medical Biological Agency, Moscow, Russia

2 Federal Medical Biological Agency, Moscow, Russia

Popular SIR models and their modifications used to generate predictions about epidemics and, specifically, the COVID-19 pandemic, are inadequate. The aim of this study was to find the laws describing the probability of infection in a biological object. Using theoretical methods of research based on the probability theory, we constructed the laws describing the probability of infection in a human depending on the infective dose and considering the temporal characteristics of a given infection. The so-called generalized time-factor law, which factors in the time of onset and the duration of an infectious disease, was found to be the most general. Among its special cases are the law describing the probability of infection developing by some point in time $t$, depending on the infective dose, and the law that does not factor in the time of onset. The study produced a full list of quantitative characteristics of pathogen virulence. The laws described in the study help to solve practical tasks and should lie at the core of mathematical epidemiological modeling.

Keywords: infective dose, probability of infection, incubation period, duration of disease, quantitative characteristics of pathogen, laws of disease

Author contribution: All authors equally contributed to the methodology of the study, data acquisition, analysis and interpretation. All author participated in drafting the manuscript and editing its final version.

$\triangle$ Correspondence should be addressed: Alexandr M. Karmishin

Shchukinskaya, 5/6, Moscow, 123182; akarmishin@cspmz.ru

Received: 16.02.2021 Accepted: 05.03.2021 Published online: 18.03.2021

DOI: $10.47183 /$ mes.2021.007

\section{ВЕРОЯТНОСТЬ ВОЗНИКНОВЕНИЯ ИНФЕКЦИОННОГО ЗАБОЛЕВАНИЯ ЧЕЛОВЕКА ПРИ ЭПИДЕМИИ}

\author{
А. М. Кармишин ${ }^{1 凶}$, И. В. Борисевич², В. И. Скворцова², А. А. Горяев¹, С. М. Юдин
}

${ }^{1}$ Центр стратегического планирования и управления медико-биологическими рисками здоровью Федерального медико-биологического агентства, Москва, Россия

2 Федеральное медико-биологическое агентство, Москва, Россия

\begin{abstract}
Применяющиеся на практике для описания развития эпидемии, в том числе и эпидемии COVID-19, SIR-модели и их различные модификации оказались несостоятельными. Целью работы было обосновать законы, описывающие вероятность возникновения инфекционного заболевания биообъекта. С помощью теоретических методов исследования, основанных на теории вероятностей, обоснованы законы, описывающие вероятность возникновения инфекционного заболевания человека в зависимости от инфицирующей дозы с учетом временных характеристик реализации поражающего действия патогена. Показано, что наиболее общим является так называемый обобщенный факторно-временной закон заболевания, учитывающий время наступления и длительность заболевания. Из него следуют частные случаи: закон, описывающий вероятность заболевания к заданному моменту времени $t$ и без учета времени наступления заболевания в зависимости от инфицирующей дозы патогена. Дано обоснование полного перечня количественных характеристик вирулентности патогена. Эти законы позволяют решать различные практически важные задачи и должны лежать в основе методов математического моделирования развития эпидемического процесса.
\end{abstract}

Ключевые слова: инфицирующая доза, вероятность заболевания, инкубационный период, длительность заболевания, количественные характеристики патогена, законы заболевания

Вклад авторов: все авторы внесли значимый вклад в разработку методики исследования, получение, анализ и интерпретацию данных. Участвовали в подготовке черновика рукописи и ее редактировании, а также в подготовке финального варианта статьи.

$\triangle$ Для корреспонденции: Александр Михайлович Кармишин ул. Щукинская, д. 5/6, г. Москва, 123182; akarmishin@cspmz.ru

Статья получена: 16.02.2021 Статья принята к печати: 05.03.2021 Опубликована онлайн: 18.03.2021

DOI: $10.47183 /$ mes.2021.007

The COVID-19 pandemic, which began in China in late November/early December 2019 [1], has raised the need for an adequate mathematical model that would accurately forecast epidemiological metrics, including the total number of cases and deaths, timeline, etc. Predictions generated by popular SIR models [2, 3] and their modifications turned out to be wrong because such models are based on false assumptions about how infection develops both in an individual and in the entire population. For example, such models predict the number of infected individuals at a given point in time from the number of contacts made by susceptibles and infectives, but not from the infective dose, which actually determines the probability of infection.

Similar to industrial accidents at hazardous facilities [4, 5], an epidemic should be described at 3 interrelated levels of generalization:
1) the low generalization level (with a focus on a hostpathogen interaction), which involves a) providing mathematical reasoning for the laws describing how a pathogen or a group of different pathogens establish an infection in a human or a nonhuman biological object and b) virulence assessment for each route of entry into the host;

2) the medium generalization level (with a focus on the transmission/spread of a studied infection in a population), which describes the infective dose received by a human or a non-human biological object via each route of transmission;

3) the high generalization level, which describes the integral spatiotemporal parameters of infection spread.

This article focuses on the first (low) generalization level, i.e. infection with one pathogen type.

The aim of this study was to find the laws describing the probability of infection in a human or a non-human biological object. 


\section{METHODS}

The laws describing how infection is established in a human or a non-human biological object can be constructed theoretically or from experimental data. This article presents the results of theoretical research.

Importantly, the main quantitative characteristic of a pathogen that determines the probability of infection or death of a biological object is the infective dose $D$, as opposed to contact between a susceptible and infective individuals.

Similar to the concept of the toxic dose of toxic chemicals [6], an infective dose is the amount of pathogen (a biohazardous agent, $\mathrm{BHA}$ ) entering the organism. This dose can be expressed in BHA mass units or special units like CFU (colony forming units), PFU (plaque forming units) and au (arbitrary units).

In order to find the laws describing how infection is established in a human or a non-human biological object, the following situations should be considered:

- exposure to different infective doses of one or a variety of pathogens, temporal characteristics of the infection not being accounted for;

- exposure to different infective doses of one or a variety of pathogens, time to onset of signs and symptoms being factored in;

- exposure to different infective doses of one or a variety of pathogens, time to onset $t$ and duration $\tau$ (time to recovery) being factored in.

Obviously, the second situation is more general than the first, and the third situation is more general than the first two.

Graphs included in the article were constructed in Microsoft Office Excel 2013 (Microsoft; USA).

\section{RESULTS}

Using the toxicity of chemical agents or pharmaceutical drugs as an analogy [6], the simplest problem, in our case, can be set up as follows.

Let us assume that when a pathogen gains access to a given host type (e.g. an adult human) via a given route of entry, it is expected to produce a specific effect (a mild, moderate, severe or critical infectious disease). Because humans differ in their immune status, the infective dose needed to produce this effect will vary between the exposed hosts. Therefore, the amount of pathogen capable of producing a certain effect (evoking a certain response) can be considered a continuous random variable.

According to the probability theory, a random variable is best described by its distribution law; the distribution law of a continuous random variable can be described by:

- a uni- or multivariate probability density function;

- a probability distribution function of the considered random variable (integral function).

The probability density function $\varphi(\widetilde{D})$ of the random infective dose (ID) value $D$ which elicits a certain response in a human or a non-human biological object is shown in Fig. 1.

By definition,

$$
\varphi(\widetilde{D})=\frac{d N}{N d D},
$$

where $\mathrm{dN}$ is the number of objects for which the random ID value eliciting a certain response falls within a range between $\widetilde{D}$ and $\widetilde{D}+d \widetilde{D}$

$N$ is the total number of objects;

$\frac{d N}{N}$ is the proportion of objects for which the random ID value evoking a certain response ranges from $\widetilde{D}$ to $\widetilde{D}+d \widetilde{D}$ if $N$ is relatively high, this proportion can be interpreted as the probability $d P$ of the ID that evokes a certain response falling within the range between $\widetilde{D}$ and $\widetilde{D}+d \widetilde{D}$; so

$$
\varphi(\widetilde{D})=\frac{d N}{N d D}=\frac{d P}{d D} .
$$

By definition, the distribution function (Fig. 2) describes the probability of the random ID value that elicits a certain response in a biological object being lower than D, i.e. $F(D)=P(\widetilde{D}<D)$.

Then, if a biological object is exposed to some infective dose $D$ at $P=F(D)$, the random ID value capable of causing infection in this biological object will be lower than the applied dose; so, the harmful effects of the pathogen will not be below a given level at $P=F(D)$ (Fig. 3).

Similar to toxic chemicals leaking during industrial accidents [6-8], the following definition can be given:

The relationship between the probability of infection whose severity is not below a given level and the infective dose is called the hazard factor law (HFL).

In general, the integral representation of this law takes the form of:

$$
P=\int_{0}^{D} \varphi(\widetilde{D}) d \widetilde{D} .
$$

This law is schematically shown in Fig. 3. Its specific representations are based on the data generated by experiments on animals. If an object is exposed to multiple hazards, the subintegral function from expression (1) can be represented by the normal or log-normal distribution, the Weibull or gamma distribution, or approximations by linear equations, the logistic curve, etc. [5].

It should be noted that when experimental data are processed, it is often impossible to favor one type of distribution

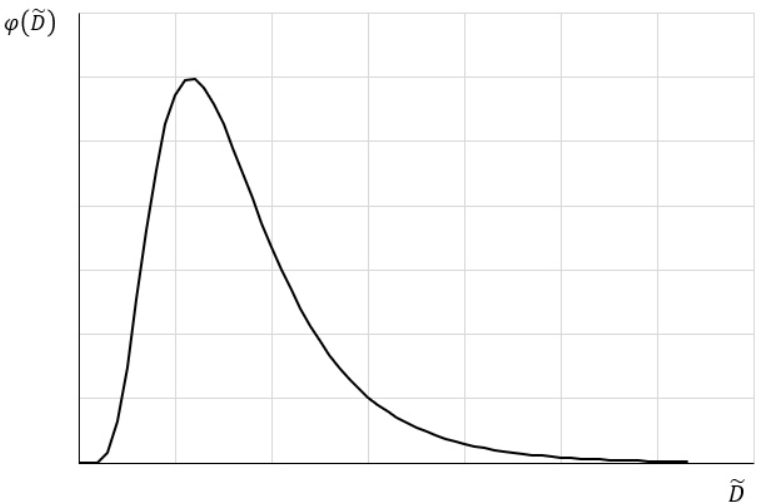

Fig. 1. The probability density function of the infective dose $D$ eliciting a specific response in a human or a non-human biological object

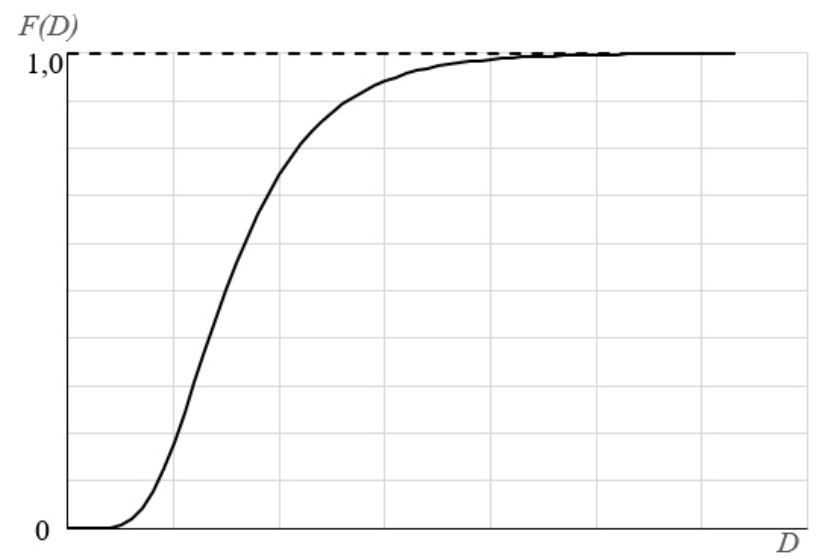

Fig. 2. The probability distribution function of the infective dose eliciting a certain response in a human or a non-human biological object 
because the obtained experimental data conform to different types of distribution.

However, when more than one random variable is included in the equation (the infective dose, time to onset of symptoms, duration of the disease), i. e. we deal with a multivariate random variable, the situation with the distribution type clears up.

Let us consider exposure to one or a variety of pathogens and account for time to onset of mild, moderate, severe or critical symptoms.

According to experimental data, time between exposure to a given infective dose and onset of clinical symptoms of various severity (the incubation period), including death, is a random variable (conditional probability distribution of one random variable in the presence of another fixed variable). Typical time to onset characterized by mathematical expectations, modal or median times correlates with the actual exposure dose.

By analogy with some other studies [6-8], we conclude that the infective dose evoking a specific response and time to its onset are continuous correlated random variables. The probability density function $\varphi(\widetilde{D}, \tilde{t})$ for such two-dimensional random variables is shown in Fig. 4. In practice, it is often required to calculate the probability of infection developing by a certain point in time $t$ or the likelihood of death. This metric can be calculated using the formula [5-8]:

$$
P=\int_{0}^{D} \int_{0}^{t} \varphi(\widetilde{D}, \tilde{t}) \widetilde{d D} d \tilde{t}
$$

Expression (2) is a common integral representation of a solution to the problem of determining the probability of developing symptoms at or above the specified severity level by some point in time $t$ depending on the infective dose; it is referred to as the hazard time-factor law (HTFL).

Thus, this law describes the probability of developing an infectious disease at or above the specified severity level by the point in time t depending on the actual infective dose (Fig. 5) [8].

In a special case, if time of onset from expression (2) approaches infinity, the expression takes the form of the hazard factor law (1). Therefore, at this stage of analysis we arrive at the conclusion about the form of subintegral functions from expressions (1) and (2).

The only known type of distribution for continuous random variables existing under the probability theory is the normal type. However, it cannot be used to solve the problem set in this paper because the normal distribution domain $(-\infty ; \infty)$ does not coincide with the domain of random variables $[0 ; \infty]$. There are no laws of multivariate Weibull distributions, gamma distributions or the like that could, in a limiting or special case, produce a Weibull or gamma distribution or a Weibull-gamma distribution [5].

About 15 years ago, we were working on a mathematical model describing the combined effect of bioactive substances, such as pharmaceutical drugs and toxic chemicals, and discovered a multivariate log-normal distribution of continuous correlated random variables [6]. Now, in the case of death from infection, the bivariate probability density function from expression (2) can take the following form:

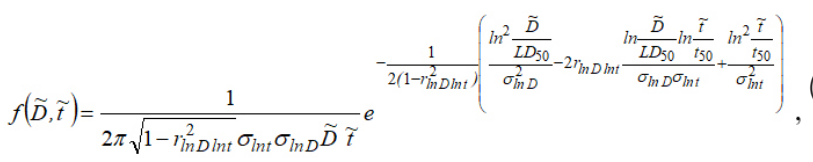

where $L D_{50}, t_{50}, \sigma_{\mathrm{InD}}, \sigma_{\mathrm{Int}}$ and $r_{\text {InDint }}$ are parameters of the equation.
If an object is exposed to a fixed amount of pathogen (infective dose), then time to onset of symptoms at or above the specified severity level (incubation time) is a continuous random

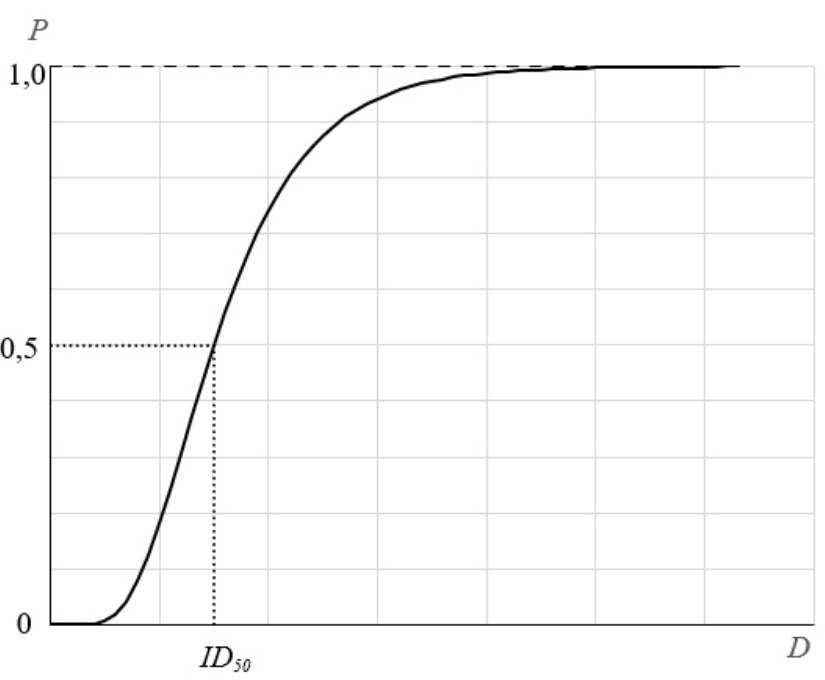

Fig. 3. The hazard factor law

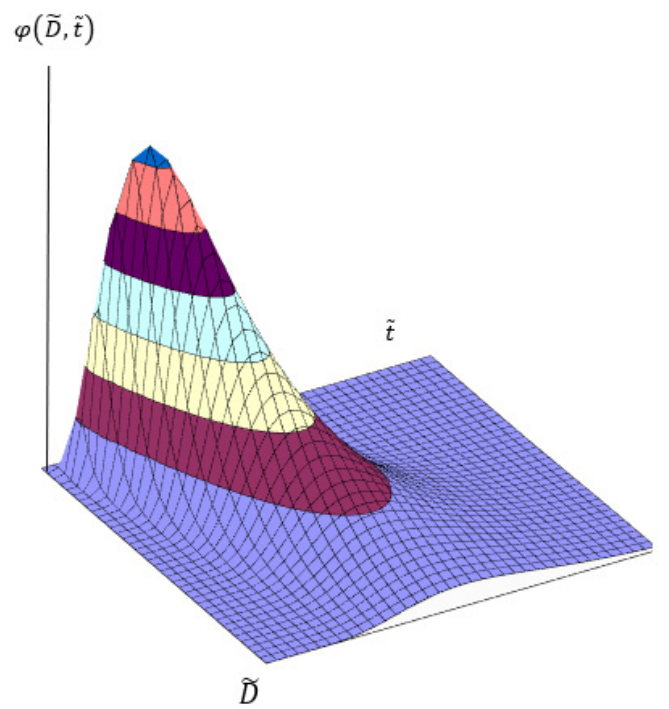

Fig. 4. The probability density function for random values of the infective dose ID causing a specific effect and time of onset.

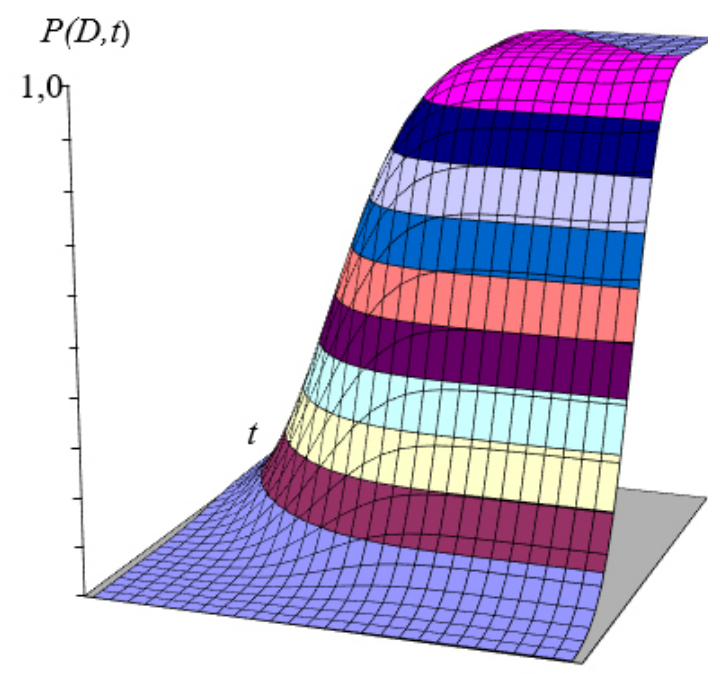

$D$

Fig. 5. The hazard time-factor law 
variable characterized by log-normal distribution [5-8]. The conditional probability distribution of random time to onset (for symptoms at or above the specified severity level) describing the probability $P(t)$ of this random time being shorter than time $t$ will take the following integral form:

$$
P(t)=0,5\left[1+e r f\left(\sqrt{k_{l n t}^{*}} \ln \frac{t}{t_{50}^{*}}\right)\right],
$$

where $t_{50}^{*}$ is median time to onset of symptoms at or above the specified severity level developing in response to a specific infective dose, expressed in days;

$k_{l_{\mathrm{n} t}}^{*}$ is a parameter of the equation.

Parameters $t_{50}^{*}$ and $k_{l n t}^{*}$ are defined using quantitative characteristics of pathogen virulence and the actual infective dose as shown below $[6,8]$ :

$$
\ln t_{50}^{*}=\ln t_{50}+r_{\ln D \ln t} \frac{\sqrt{k_{\ln D}}}{\sqrt{k_{\operatorname{lnt} t}}} \ln \frac{D}{D_{50}}, \quad \sqrt{k_{\ln t}^{*}}=\frac{\sqrt{k_{\ln t}}}{\sqrt{1-r_{\ln D \ln t}^{2}}} ; \quad \sqrt{k}=\frac{1}{\sqrt{2} \sigma} .
$$

According to experimental data, the amount of pathogen that causes a disease in a human biological object, disease incubation time and duration (time from onset of clinical symptoms to recovery) are continuous random variables.

In 2007, it was demonstrated that the probability of the harmful effect (which, in our case, is infection) that is not less than a given severity by the time $t$ and for a duration $\tau$ (that not less than a given one) can be defined as follows [8]:

$$
P=\int_{0}^{D} \int_{0}^{t} \int_{\tau}^{\infty} f(\widetilde{D}, \tilde{t}, \tilde{\tau}) d \widetilde{D} d \tilde{t} d \tilde{\tau},
$$

where $f(\widetilde{D}, \tilde{t}, \tilde{\tau})$;-variate log-normal distribution density of continuous correlated random values: the infective dose $\widetilde{D}$ capable of causing infection at or above the specified severity level, time of onset $\tilde{t}$ and duration of infection $\tilde{\tau}$, characterized by 9 parameters, which, in the case of a pathogen, are quantitative characteristics of pathogen virulence

$$
\begin{aligned}
& f(\widetilde{D}, \tilde{t}, \tilde{\tau})=\frac{1}{(2 \pi)^{1,5} \sqrt{\Delta_{1}} \tilde{D} \tilde{t} \tilde{\tau} \sigma_{h D} \sigma_{h H} \sigma_{h t}} e^{-\frac{1}{2 \Delta_{l}}[A+B]},
\end{aligned}
$$

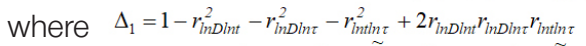

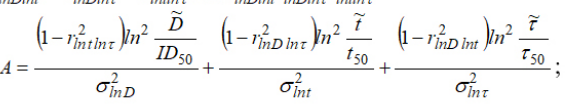

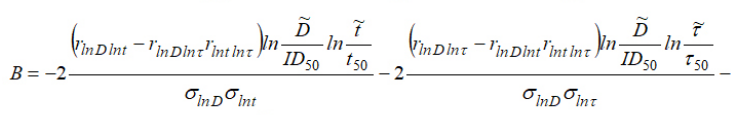

$$
\begin{aligned}
& -2 \frac{\left(r_{\operatorname{lnthn}}-r_{\ln D \ln \tau} r_{\ln D h n}\right) \ln \frac{\tilde{\tau}}{t_{50}} \ln \frac{\tilde{\tau}}{\tau_{50}}}{\sigma_{\operatorname{lnt}} \sigma_{\ln \tau}}
\end{aligned}
$$

This probability is referred to as generalized HTFL [8]. If duration of an infectious disease is not included in the equation, as is the case with deaths from infection, then, assuming that (6) $\tau=0$, we will arrive at HTFL (2).

If the generalized HTFL does not account for the timeline of infection, then, assuming that $t=\infty$ and $\tau=0$, we will arrive at HFL (1):

$$
P=\int_{0}^{D} f(\widetilde{D}) d \widetilde{D}=0,5\left[1+e r f\left(\frac{1}{\sqrt{2} \sigma_{\ln D}} \ln \frac{D}{D_{50}}\right)\right]=0,5\left[1+e r f\left(\sqrt{k_{\ln D}} \ln T\right)\right],
$$

because

$$
f(\widetilde{D})=\frac{1}{\sqrt{2 \pi} \sigma_{\ln D} \widetilde{D}} e^{-\frac{\ln ^{2} \frac{\tilde{D}}{I_{50}}}{2 \sigma_{\ln D}^{2}}}, \quad \sqrt{k}=\frac{1}{\sqrt{2} \sigma}
$$

where erf(u) is the integral of error function

$$
\operatorname{erf}(u)=\frac{2}{\sqrt{\pi}} \int_{0}^{u} e^{\frac{t^{2}}{2}} d t
$$

The list of quantitative characteristics of pathogen virulence in the case of exposure to one pathogen, their probability and physical interpretation are provided in Table.

Thus, the problem formulated at the beginning of this study is now completely theoretically solved.

Virulence depends on the species and strain of the studied pathogen, the route of entry (inhalation, ingestion, through mucous membranes) and the type of the biological object exposed to the pathogen (adults, children, the elderly, individuals with chronic conditions). Virulence should be experimentally assessed at the lab using model objects. The obtained results are then expected to be translated to humans.

Methods used to determine quantitative characteristics of virulence have been subjected to critical analysis. Among such methods are Kärber's method [9], Finney's probit analysis [10] and Bliss's probit analysis [11]. Using the method of moments, maximal likelihood estimation and the method of least squares, researchers designed ways to measure 9 toxicological (virological) parameters of bioactive agents (pathogens) based on primary data from laboratory studies on model objects [8].

There is another important issue that needs to be discussed. The laws covered by this study are referred to as conditional static (deterministic) laws. In real life, the infective pathogen dose is a stochastic variable due to a number of subjective and objective reasons [8]. At the same time, quantitative characteristics of virulence are population parameters, i.e. deterministic variables. On the other hand, given the methods for their determination, they are estimates of the general population parameters and, therefore, are continuous random variables (this is a fundamental property of estimates).

Therefore, the studied probabilities of infection are functions of continuous random variables and are stochastic themselves. This raises the question of accounting for the random nature of variables in the laws described above. This problem can be discussed and solved under the stochastic theory of infection, the emergent, independent field of research [8, 12-17].

The literature offers a wealth of data on the incubation period: its minimum $t_{\min }$, maximum $t_{\max }$ and sometimes average duration $[18,19]$. To a first approximation, such data provide an insight into the temporal characteristics of virulence. Assuming that the minimum and maximum duration of the incubation period reported by the literature are in agreement with the 0.95 probability of random incubation period duration falling within this range, the following quantitative characteristics can be calculated:

- the median duration of the incubation period

$$
I t_{50}=\sqrt{t_{\min } t_{\max }}
$$

- the mean squared error $\sigma_{\operatorname{lnt}}$

$$
\sigma_{\text {lnt }}=0,25 \ln \frac{t_{\max }}{t_{\min }}
$$

However, more accurate estimates can be obtained in special experiments on model objects, followed by their translation to humans [8].

\section{DISCUSSION}

Our theoretical research allowed us to find the laws describing the probability of infection after exposure to one pathogen type, depending on the infective dose and considering the temporal characteristics of a given infection. The correctness of these laws was confirmed by dimensional analysis and their correct behavior in limiting and special cases.

An important practical implication of this theoretical research is the complete list of quantitative characteristics of virulence. It is important to know 9 or 5 quantitative characteristics of virulence, for reversible and irreversible effects, respectively. 
Table. The full list of quantitative characteristics of pathogen virulence in the case of exposure to one pathogen

\begin{tabular}{|c|c|c|c|}
\hline \multirow{2}{*}{ Characteristic } & \multirow{2}{*}{ Units } & \multicolumn{2}{|c|}{ Interpretation } \\
\hline & & Probability (statistical) & Physical \\
\hline$I D_{50}, L D_{50}$ & mg (au, PFU, CFU) & \multirow[b]{2}{*}{$\begin{array}{l}\text { Median infective and lethal doses (exposure doses) } \\
\text { causing an infectious disease of given severity or death }\end{array}$} & \multirow[b]{2}{*}{$\begin{array}{l}\text { Infective (exposure) doses for which the probability of } \\
\text { infection or death is } 0.5\end{array}$} \\
\hline$I C T_{50}, L C T_{50}$ & $\begin{array}{l}\operatorname{mg} \cdot \min \cdot L^{-1} \\
\left(\mathrm{au} \cdot \min \cdot L^{-1}\right. \\
\left.\text { БOE} \cdot \min \cdot L^{-1}\right)\end{array}$ & & \\
\hline$I t_{50}, \quad L t_{50}$ & \multirow{2}{*}{ hours, days. } & $\begin{array}{l}\text { Median time to infection of given severity following } \\
\text { exposure to the median infective dose }\end{array}$ & $\begin{array}{l}\text { Period after which all infected persons exposed to the } \\
\text { median infective dose will develop clinical symptoms or } \\
\text { die at } 0.5 \text { probability }\end{array}$ \\
\hline$\Pi_{50}$ & & $\begin{array}{l}\text { Median time of random duration of an infectious } \\
\text { disease following exposure to median ID }\end{array}$ & $\begin{array}{l}\text { Period during which the infected individual exposed to } \\
\text { the median infective dose will recover at } 0.5 \text { probability }\end{array}$ \\
\hline$\sigma_{\operatorname{lnD}}$ & - & $\begin{array}{l}\text { Standard deviation (SD) of the natural logarithm of a } \\
\text { random ID value causing infection or death }\end{array}$ & $\begin{array}{l}\text { Characterizes the homogeneity (heterogeneity) of a } \\
\text { given population in terms of its susceptibility to infection }\end{array}$ \\
\hline$\sigma_{\text {Int }}$ & - & $\begin{array}{l}\text { SD of the natural logarithm of random time to onset of } \\
\text { infection or death }\end{array}$ & $\begin{array}{l}\text { Characterizes the homogeneity of a given population in } \\
\text { terms of time to onset of clinical signs and symptoms }\end{array}$ \\
\hline$\sigma_{\ln \tau}$ & - & $\begin{array}{c}\text { SD of the natural logarithm of random infection } \\
\text { duration }\end{array}$ & $\begin{array}{l}\text { Characterizes the homogeneity (heterogeneity) of a } \\
\text { given population in terms of disease duration }\end{array}$ \\
\hline$r_{\text {InDint }}$ & - & $\begin{array}{c}\text { Correlation coefficient of the natural logarithms of } \\
\text { - random infective dose causing infection or death and } \\
\text { time of onset; } \\
\text { - random infective dose causing infection and the } \\
\text { duration of the infectious disease; } \\
\text { - random time of onset and the duration of the } \\
\text { infectious disease }\end{array}$ & $\begin{array}{l}\text { Characterizes the relationship between complex } \\
\text { processes underlying the development of harmful } \\
\text { effects of a bioactive compound on a biological object } \\
\text { over time } \\
-1 \leq r_{\text {hDInt }} \leq 0 \\
0 \leq r_{\text {InDInt }} \leq 1 \\
-1 \leq r_{\text {Intlnt }} \leq 0\end{array}$ \\
\hline
\end{tabular}

Today, these quantitative characteristics are almost unknown, which is a serious setback for accurate epidemic modeling.

At present, the probability of establishing an infection is described based on the number of contacts between susceptibles and infectives [2, 3, 20, 21], which is wrong in principle.

\section{CONCLUSION}

We have constructed the hazard factor law, the hazard timefactor law and the generalized time-factor laws describing the probability of infection in humans and non-human biological objects (like agricultural animals) following exposure to one as opposed to a variety of pathogens. These laws help in solving practical tasks and should lie at the core of mathematical epidemiological modeling.

In order to successfully solve practical epidemiological tasks, further research should focus on identifying all quantitative characteristics of pathogens for every route of entry into the body and the obtained data should be compiled into a comprehensive database.

\section{References}

1. Sajt Vsemirnoj organizaciizdravoohranenija. Available from: https:// www.who.int/emergencies/diseases/novel-coronavirus-2019 (data obrashhenija 21 aprelja 2020 g.). Russian.

2. Harko T, Lobo FSN, Mak MK. Exact analytical solutions of the Susceptible-Infected-Recovered (SIR) epidemic model and of the SIR model with equal death and birth rates. Applied Mathematics and Computation. 2014 236: 184-194. DOI: 10.1016/j. amc.2014.03.030. Sir.

3. Bejli N. Matematika v biologii i medicine. M.: Mir, 1970. Russian.

4. Karmishin AM, Semochkina EA, Chernykh AO. Kvalimetricheskoe opisanie himicheskoj bezopasnosti: tezisy doklada. $\vee$ sbornike: Materialy Vserossijskoj nauchno-prakticheskoj konferencii, posvjashhennoj 55 letiju FGUP «NII GPJeCh» FMBA Rossii, 17 fevralja 2017 g., g. Sankt-Peterburg. SPb.: Izd. Politehn. un-ta, 2017; s. 70-72. Russian.

5. Karmishin AM, Gumenyuk VI, Makarov ML. Teoreticheskie aspekty obosnovanija kolichestvennyh pokazatelej opasnosti avarij potencial'no opasnyh promyshlennyh ob"ektov/zhurnal Problemy bezopasnosti i chrezvychajnyh situacij. M.: VINITI, 2019; s. 51-66. Russian.

6. Karmishin AM, Kireev VA. Matematicheskie metody farmakologii i toksikologii. M.: VU RHB zashhity, 2005; 180 s. Russian.

7. Karmishin AM. Uspehi teoreticheskoj toksikologii i farmakologii/ tezisy doklada. V sbornike: Materialy Vserossijskoj nauchnoprakticheskoj konferencii, posvjashhennoj 55-letiju FGUP «NII GPJeCh» FMBA Rossii, 17 fevralja 2017 g., g. Sankt-Peterburg. SPb.: izd. Politehn. un-ta, 2017; s. 68-70. Russian.

8. Karmishin AM, Kireev VA, Berezin Gl, Afanasyev RV. Matematicheskie metody farmakologii, toksikologii i radiobiologii. M.: APR, 2011; 330 s. Russian.

9. Kärber G. Beitrag sur kollektiven Behandlung pharmakologisher reihen-versucher. Arch exp Path. 1931; 162: 480-3.

10. Finney DJ. Probit analisis. Cambridg: Cambridg University Press, 1977 ; p. 333

11. Bliss Cl. The method of probits. Scince. 1934; 79: 38-39.

12. Karmishin AM, Gumenyuk VI, Zaharov VP. Obosnovanie zakona raspredelenija sluchajnoj velichiny ushherba pri tehnogennoj avarii. V sbornike: Nedelja nauki SPbPU 14-19 nojabrja 2016 g.: materialy nauchnoj konferencii s mezhdunarodnym uchastiem. Luchshie doklady. SPb.: SPBPU, 2016; 406-11. Russian.

13. Karmishin AM, Kireev VA, Zaonegin SV, Gladkih VD, i dr. K voprosu ocenki toksichnosti himicheski opasnyh veshhestv pri chrezvychajnyh situacijah himicheskoj prirody. Himicheskaja i biologicheskaja bezopasnost'. Special'nyj vypusk, posvjashhennyj Federal'noj celevoj programme «Nacional'naja sistema himicheskoj i biologicheskoj bezopasnosti Rossijskoj Federacii (2009-20014 gody)». 2012: 117-21. Russian.

14. Karmishin AM, Kireev VA, Gumenyuk VI. Ocenka prostranstvennovremennyh pokazatelej opasnosti tehnogennyh avarij. V sbornike: Bezopasnost' $v$ chrezvychajnyh situacijah: sbornik nauchnyh trudov $V$ vserossijskoj nauchno-prakticheskoj konferencii. SPb.: izd-vo Politehn. un-ta, 2013; s. 70-77. Russian.

15. Karmishin AM, Gumenyuk VI, Kireev VA. Problemnye voprosy promyshlennoj bezopasnosti. Nauchno-tehnicheskie vedomosti 
SPbGPU. 2013; 2 (178): 320-4. Russian.

16. Karmishin AM, Kireev VA, Gumenyuk VI. K voprosu o kolichestvennyh pokazateljah opasnosti tehnogennyh avarij. Nauchno-tehnicheskie vedomosti SPb. 2013; 2 (171): 281-8. Russian.

17. Karmishin AM, Karnjushkin Al, Reznichek VF. Gumenyuk VI. Obshhie integral'nye predstavlenija pokazatelej opasnosti tehnogennyh avarij. Bezopasnost' v tehnosfere. 2013; 6: 38-45. Russian.

18. Bogomolov BP. Infekcionnye bolezni: neotlozhnaja diagnostika,

\section{Литература}

1. Сайт Всемирной организации здравоохранения. Доступно по ссылке: https://www.who.int/emergencies/diseases/novelcoronavirus-2019 (дата обращения 21 апреля 2020 г.).

2. Harko T, Lobo FSN, Mak MK. Exact analytical solutions of the Susceptible-Infected-Recovered (SIR) epidemic model and of the SIR model with equal death and birth rates. Applied Mathematics and Computation. 2014 236: 184-194. DOI: 10.1016/j. amc.2014.03.030. Sir.

3. Бейли Н. Математика в биологии и медицине. М.: Мир, 1970.

4. Кармишин А. М., Семочкина Е. А., Черных А. О. Квалиметрическое описание химической безопасности: тезисы доклада. В сборнике: Материалы Всероссийской научно-практической конференции, посвященной 55 летию ФГУП «НИИ ГПЭЧ» ФМБА России, 17 феевраля 2017 г., г. Санкт-Петербург. СПб.: Изд. Политехн. ун-та, 2017; с. 70-72.

5. Кармишин А. М., Гуменюк В. И., Макаров М. Л. Теоретические аспекты обоснования количественных показателей опасности аварий потенциально опасных промышленных объектов/ журнал Проблемы безопасности и чрезвычайных ситуаций. М.: ВИНИТИ, 2019; с. 51-66.

6. Кармишин А. М., Киреев В.А. Математические методы фармакологии и токсикологии. М.: ВУ РХБ защиты, 2005; 180 с.

7. Кармишин А. М. Успехи теоретической токсикологии и фармакологии/ тезисы доклада. В сборнике: Материалы Всероссийской научно-практической конференции, посвященной 55-летию ФГУП «НИИ ГПЭЧ» ФМБА России, 17 февраля 2017 г., г. Санкт-Петербург. СПб.: изд. Политехн. унта, 2017; с. 68-70.

8. Кармишин А. М., Киреев В. А., Березин Г. И., Афанасьев Р. В. Математические методы фармакологии, токсикологии и радиобиологии. М.: АПР, 2011; 330 с.

9. Kärber G. Beitrag sur kollektiven Behandlung pharmakologisher reihen-versucher. Arch exp Path. 1931; 162: 480-3.

10. Finney DJ. Probit analisis. Cambridg: Cambridg University Press, 1977; p. 333

11. Bliss Cl. The method of probits. Scince. 1934; 79: 38-39.

12. Кармишин А. М., Гуменюк В. И., Захаров В. П. Обоснование закона распределения случайной величины ущерба при lechenie, profilaktika. M.: N'judiamed, 2007; 652 s. Russian.

19. Pokrovskij $\mathrm{VI}$, i dr. Infekcionnye bolezni i jepidemiologija. M.: GEOTAR-MEDIA, 2013; 1007 s. Russian.

20. Tamm MV. Koronavirusnaja infekcija v Moskve: prognozy i scenarii. Sovremennaja farmakojekonomika i farmakojepidemiologija. 2020; 13 (1): 43-51. Russian.

21. Dostupno po ssylke (data obrashhenija 4.11.2020): https://www. newsru.com/russia/09oct2020/sbercovidpeak.html. Russian.

техногенной аварии. В сборнике: Неделя науки СПбПУ 14-19 ноября 2016 г.: материалы научной консреренции с международным участием. Лучшие доклады. СПб.: СПБПу, 2016; 406-11.

13. Кармишин А. М., Киреев В. А., Заонегин С. В., Гладких В. Д. и др. К вопросу оценки токсичности химически опасных веществ при чрезвычайных ситуациях химической природы. Химическая и биологическая безопасность. Специальный выпуск, посвященный Федеральной целевой программе «Национальная система химической и биологической безопасности Российской Федерации (2009-2014 годы)». 2012; c. 117-21.

14. Кармишин А. М., Киреев В. А., Гуменюк В. И. Оценка пространственно-временных показателей опасности техногенных аварий. В сборнике: Безопасность в чрезвычайных ситуациях: сборник научных трудов $\bigvee$ всероссийской научнопрактической конференции. СПб.: изд-во Политехн. ун-та, 2013; c. 70-77.

15. Кармишин А. М., Гуменюк В. И., Киреев В. А. Проблемные вопросы промышленной безопасности. Научно-технические ведомости СПбГПУ. 2013; 2 (178): 320-4.

16. Кармишин А. М., Киреев В. А., Гуменюк В. И. К вопросу о количественных показателях опасности техногенных аварий. Научно-технические ведомости. СПб., 2013; 2 (171): 281-8.

17. Кармишин А. М., Карнюшкин А. И., Резничек В. Ф. Гуменюк В. И. Общие интегральные представления показателей опасности техногенных аварий. Безопасность в техносфере. 2013; 6: 38-45.

18. Богомолов Б. П. Инфекционные болезни: неотложная диагностика, лечение, профилактика. М.: Ньюдиамед, 2007; $652 \mathrm{c}$.

19. Покровский В. И. и др. Инфекционные болезни и эпидемиология. М.: ГЕОТАР-МЕДИА, 2013; 1007 с.

20. Тамм М. В. Коронавирусная инфекция в Москве: прогнозы и сценарии. Современная фармакоэкономика и фармакоэпидемиология. 2020; 13 (1): 43-51.

21. Доступно по ссылке (дата обращения 4.11.2020): https:// www.newsru.com/russia/09oct2020/sbercovidpeak.html. 